\title{
The impact of some inorganic substances on change in body mass of Tenebrio molitor (Coleoptera, Tenebrionidae) larvae in a laboratory experiment
}

\author{
Vladyslav O. Martynov, Viktor V. Brygadyrenko* \\ Department of Zoology and Ecology, Faculty of Biology and Ecology, \\ Oles Honchar Dnipro National University, Gagarin Ave. 72, Dnipro, 49010, Ukraine
}

\begin{abstract}
Martynov, V.O., Brygadyrenko, V.V., 2018. The impact of some inorganic substances on change in body mass of Tenebrio molitor (Coleoptera, Tenebrionidae) larvae in a laboratory experiment. Folia Oecologica, 45: 24-32.
\end{abstract}

Addition of low concentrations of metal ions to the diet of saprophagous insects can impact on their metabolism over a short period of time, causing an increase or decrease in their body mass. This article presents a 14-day laboratory experiment evaluating the changes in the body mass of larval stage 3 of Tenebrio molitor (Linnaeus, 1758) induced by adding different inorganic substances (350 $\mathrm{mg} \mathrm{kg}^{-1}$ of dry fodder) to the diet of the larvae. Following the addition of inorganic substances to the fodder, the most marked differences compared to the control were observed in the groups which consumed substrate with lead nitrate (the mass of the larvae increased on average by $102.6 \%$ compared to increase in mass in the control variant of the experiments), cobalt nitrate (by $96.9 \%$ ), calcium chloride (by $89.1 \%$ ) sodium triphosphate (by $86.0 \%$ ), zinc chloride (by 83.5\%). A nonsignificant effect (a tendency of increase in the body mass) on $T$. molitor larvae was caused by manganese sulfate (by $57.8 \%$ ), aluminium nitrate (by $57.3 \%$ ), iron oxide (by $51.5 \%$ ), barium nitrate (by 47.9\%), orthophosphoric acid (by 47.4\%), manganese chloride (by $46.5 \%$ ), calcium carbonate (by $27.7 \%$ ), iron sulfate (by $24.2 \%$ ) and ammonium heptamolybdate (by $-7.5 \%$ ). Therefore, 5 out of the 15 studied inorganic substances significantly stimulated the increase in the body weight of $T$. molitor larvae, and 7 manifested these capacities at the level of tendency (stimulated an increase in body weight averaging $43-58 \%$ over the 14-day experiment). The obtained data indicate a necessity for further study on the impact of inorganic pollutants on different stages of insects.

\section{Keywords}

body mass, heavy metal pollution, larvae, Tenebrionidae

\section{Introduction}

Environmental pollution is one of the most acute global ecological problems of today (DALLINGER, 1993). Among a great variety of environmental factors affecting living organisms, the main role is taken by heavy metals, principally on account of human activity. The sources for contamination of the biosphere with heavy metals include the ferrous and non-ferrous metal industries, machine building industries, accumulator battery recycling plants, auto transport, and also volcanic eruptions and dissolution of minerals and rocks. Among chemical pollutants, heavy metals are considered a factor with significant ecological and biological consequences (ANDERSON et al., 1980; Bisthoven et al., 1992; BRYGADYRENKO and RESHETNIAK, 2014; Brygadyrenko and IVANyshin, 2014, 2015; SHulman et al., 2017).

Inorganic substances (primarily, heavy metals) in spite

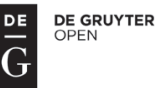

*Corresponding author:

e-mail: brigad@ua.fm

(C) 2018 Authors. This is an open access article under the CC BY-NC-ND license (http://creativecommons.org/licenses/by-nc-nd/3.0/) 
of their migration ability, are capable of bioaccumulation and specific toxic effects; in particular through food products affected by levels of heavy metals which exceed the acceptable standards, are dangerous for human and animal health (BAKER et al., 1998). The observed effects of metal ion contamination include carcinogenicity, immunotoxicity and neurotoxicity, which are considered to develop due to the formation of oxygen radicals, which cause oxidative stress and changes in physiological and biochemical characteristics of the tissues of organisms (VALKo et al., 2005).

The physiological impact of inorganic substances on human and animal organisms varies and is related to their chemical activity, their natural form and also to their concentration (BuCHWALTER and LuOMa, 2005). Many metals have pronounced capacities for forming complexes. In water, ions of these metals are hydro activated and they are able to form different hydroxi complexes, the composition of which is related to the acidity of the solution (MARTINEZ et al., 2001). If a solution includes some anions and molecules of organic compounds, metal ions form complexes of different structures and stability, therefore their biological activity varies. Thus, the issue of objective evaluation of the ecological safety of the impact of chemical toxins on organisms in the conditions of natural and anthropogenic pollution is of great significance (MARTYNOV and BRYGADYRENKO, 2017). An important role in this process is played by excessive pollution of the biosphere with inorganic pollutants, which is characterized by toxic effects which affect the main vital functions of organisms (BRYGADYRENKO and IVANYSHIN, 2014, 2015). Metal salts and inorganic acids have a nonspecific effect, which is realized by accumulation of changes in tissues and organs and manifests as fixation, blocking active centers of enzymes, which affect the condition of enzymic systems. Therefore, studying the effect of inorganic pollutants on living organisms is of great significance. There is a pressing need to develop methods for evaluating the pollutants' negative effects and methods for their elimination.

This article aims to evaluate the impact on body weight of the third stage of Tenebrio molitor Linnaeus, 1758 larvae caused by adding different inorganic substances (highly toxic, mild and low toxic) in the conditions of a laboratory experiment.

\section{Materials and methods}

The experiment used the third stage larvae of T. molitor. Before the experiment, the larvae were kept together for over a month in a single container and they were fed with the same fodder (dry oat flakes). The selection of animals for the experiment was random. The experiment was conducted in plastic cups $(0.2 \mathrm{l})$, with $36.01 \pm 0.27 \mathrm{~g}$ of dry oat flakes in each cup. The substrate was moistened from a pipette with solutions of the studied substances at a $3 \mathrm{ml}$ dose, at a concentration of $4.2 \mathrm{~g} \mathrm{l}^{-1}$ of chemically pure substances. Therefore, the concentration of the active substance in our experiment was $350 \mathrm{mg} \mathrm{kg}^{-1}$ of dry fodder.

The experiment was designed to compare the impacts of different (highly toxic, mild and low toxic) substances applied at the same concentrations and to determine the variability of reactions of $T$. molitor larvae: to assess both reduction and increase in the body weight in the particular variants of the experiment. According to BRAECKMAN et al. (1999) $\mathrm{LD}_{50}$ cadmium chloride for Aedes albopictus (Skuse, 1895) is $2.08 \mathrm{mmol} \mathrm{l}^{-1}$ or $381.3 \mathrm{mg} \mathrm{l}^{-1}$. In our experiments, the concentration of substances $\left(350 \mathrm{mg} \mathrm{kg}^{-1}\right)$ corresponded to the average lethal dose of cadmium for Ae. albopictus. The toxicity of other compounds of metals used in the experiment was much lower (Table 1). Apart from heavy metals, the experiment analyzed additions of other comparatively safe chemical compounds to the diet (Table 2) in order to study their chronic impact at low concentrations (much lower than $\mathrm{LD}_{50}$ ).

After moistening the substrate with chemical compounds, it was carefully mixed with a plastic stick for uniform distribution of the substance throughout the substrate. In the control group, we used distilled water to the same amount $(3 \mathrm{ml})$. After the solutions were added, the substrate was dried for deleting excessive moisture in order to prevent mould and prevent fungi infestations of the T. molitor larvae. Then the substrate was mixed again to prevent development of large aggregates of oat flakes, which would bind together after addition of water solutions.

Each variant of the experiment included 8 cups, each with one T. molitor individual. All variants of the experiment used 128 individuals $(120$ - in 15 variants of the experiment and 8 in the control). The containers were placed randomly on tables in a laboratory with equal illumination and temperature, not exposed to direct sunlight. Temperature fluctuations over each day were not higher than $2{ }^{\circ} \mathrm{C}\left(+18 \ldots+20^{\circ} \mathrm{C}\right)$, the duration of daylight between 09-23 August was 1,355-1,440 $\mathrm{h}$ and it was prolonged by artificial illumination to $16 \mathrm{~h}$ a day. Before the beginning and at the end of the 14-day experiment, all T. molitor individuals were weighed. The average initial body weight of the larvae equaled $46.8 \pm 3.1 \mathrm{mg}(\mathrm{x} \pm \mathrm{SD}$, $\mathrm{n}=128$ ), 14 days after the beginning of the experiment the mass of the animals had increased to $67.9 \pm 11.2 \mathrm{mg}$. The mass of the larvae was determined to an accuracy of $0.1 \mathrm{mg}$ on an analytic balance.

The results were statistically analyzed in Statistica 8.0 (Statsoft Inc., USA). The differences were considered significant at $\mathrm{P}<0.05$ (one-way ANOVA).

\section{Results}

Over the experiment, no deaths of larvae or cases of moulting were observed. The changes in the body weight of $T$. molitor larvae in the 14-day laboratory experiment concerning addition of different substances to the fodder 
Table 1. Heavy metals used in experiment involving feeding T. molitor larvae

\begin{tabular}{|c|c|c|c|c|c|c|}
\hline $\begin{array}{l}\text { Name of the } \\
\text { substance }\end{array}$ & $\begin{array}{l}\text { Chemical } \\
\text { formula }\end{array}$ & Capacities & $\begin{array}{l}\mathrm{LD}_{50} \text { (oral, Rat) }^{*} \\
\quad \mathrm{mg} \mathrm{kg}^{-1}\end{array}$ & $\begin{array}{l}\mathrm{TLV}^{* *} \\
\text { (TWA), } \\
\mathrm{mg} \mathrm{m}^{-3}\end{array}$ & $\begin{array}{l}\text { Threat level } \\
\text { to health** }^{* *}\end{array}$ & Usage \\
\hline Zinc chloride & $\mathrm{ZnCl}_{2}$ & $\begin{array}{l}\text { White hygroscopic } \\
\text { odorless crystals }\end{array}$ & 350 & 1.00 & 3 & $\begin{array}{l}\text { Metallurgy, organic synthesis, } \\
\text { textile and paper industry }\end{array}$ \\
\hline Cobalt nitrate & $\mathrm{Co}\left(\mathrm{NO}_{3}\right)_{2}$ & $\begin{array}{l}\text { Red hygroscopic } \\
\text { odorless crystals }\end{array}$ & 691 & 0.02 & 2 & $\begin{array}{l}\text { Metallurgy, organic synthesis, } \\
\text { production of pigments }\end{array}$ \\
\hline $\begin{array}{l}\text { Ammonium } \\
\text { heptamolybdate }\end{array}$ & $\left(\mathrm{NH}_{4}\right)_{6} \mathrm{Mo}_{7} \mathrm{O}_{24}$ & $\begin{array}{l}\text { White crystals well } \\
\text { soluble in water }\end{array}$ & 333 & 10.00 & 2 & $\begin{array}{l}\text { Metallurgy, analytical } \\
\text { chemistry, production of } \\
\text { ceramics and fertilizers }\end{array}$ \\
\hline $\begin{array}{l}\text { Cadmium } \\
\text { chloride }\end{array}$ & $\mathrm{CdCl}_{2}$ & $\begin{array}{l}\text { White hygroscopic } \\
\text { odorless crystals }\end{array}$ & 88 & 0.01 & 3 & $\begin{array}{l}\text { Organic synthesis, production } \\
\text { of pigments, galvanization }\end{array}$ \\
\hline $\begin{array}{l}\text { Manganese } \\
\text { sulfate }\end{array}$ & $\mathrm{MnSO}_{4}$ & $\begin{array}{l}\text { White or red-pink } \\
\text { crystals }\end{array}$ & 4,000 & 10.00 & 1 & $\begin{array}{l}\text { Organic synthesis, food } \\
\text { industry, agriculture }\end{array}$ \\
\hline $\begin{array}{l}\text { Manganese } \\
\text { chloride }\end{array}$ & $\mathrm{MnCl}_{2}$ & $\begin{array}{l}\text { Pink crystals well } \\
\text { soluble in water }\end{array}$ & 1,454 & 0.20 & 2 & $\begin{array}{l}\text { Chemical industry, battery } \\
\text { production }\end{array}$ \\
\hline Lead nitrate & $\mathrm{Pb}\left(\mathrm{NO}_{3}\right)_{2}$ & $\begin{array}{l}\text { White crystals well } \\
\text { soluble in water }\end{array}$ & 93 & 0.05 & 3 & $\begin{array}{l}\text { Chemical industry, production } \\
\text { of pigments }\end{array}$ \\
\hline $\begin{array}{l}\text { Alluminium } \\
\text { nitrate }\end{array}$ & $\mathrm{Al}\left(\mathrm{NO}_{3}\right)_{3}$ & $\begin{array}{l}\text { White hygroscopic } \\
\text { crystals }\end{array}$ & 3,632 & 2.00 & 2 & $\begin{array}{c}\text { Petrochemical industry, } \\
\text { electronics }\end{array}$ \\
\hline Barium nitrate & $\mathrm{Ba}\left(\mathrm{NO}_{3}\right)_{2}$ & $\begin{array}{l}\text { Colorless crystals } \\
\text { well soluble in } \\
\text { water }\end{array}$ & 355 & 0.50 & 2 & Manufacture of explosives \\
\hline
\end{tabular}

*according to data of Material Safety Data Sheet (MSDS) for every substance; **Threshold Limit Value (TLV) according to American Conference of Governmental Industrial Hygienists (ACGIH); ***according to Hazardous Materials Identification System.

Table 2. Inorganic substances used in the experiment involving feeding T. molitor larvae

\begin{tabular}{|c|c|c|c|c|c|c|}
\hline $\begin{array}{l}\text { Name of the } \\
\text { substance }\end{array}$ & $\begin{array}{l}\text { Chemical } \\
\text { formula }\end{array}$ & Capacities & $\begin{array}{c}\mathrm{LD}_{50} \text { (oral, } \\
\text { Rat) }^{*} \text {, } \\
\mathrm{mg} \mathrm{kg}^{-1}\end{array}$ & $\begin{array}{l}\mathrm{TLV}^{* *} \\
\text { (TWA), } \\
\mathrm{mg} \mathrm{m}^{-3}\end{array}$ & $\begin{array}{l}\text { Threat level to } \\
\text { health }^{* * *}\end{array}$ & Usage \\
\hline $\begin{array}{l}\text { Calcium } \\
\text { carbonate }\end{array}$ & $\mathrm{CaCO}_{3}$ & $\begin{array}{l}\text { White crystals insoluble in } \\
\text { water }\end{array}$ & 6,450 & 10 & 2 & $\begin{array}{l}\text { Food industry, manufacture of paints, } \\
\text { household chemistry industry }\end{array}$ \\
\hline $\begin{array}{l}\text { Calcium } \\
\text { chloride }\end{array}$ & $\mathrm{CaCl}_{2}$ & $\begin{array}{l}\text { White crystals well soluble } \\
\text { in water }\end{array}$ & 1,000 & 3 & 2 & $\begin{array}{l}\text { Metallurgy, production of construction } \\
\text { materials, food industry }\end{array}$ \\
\hline Iron sulfate & $\mathrm{FeSO}_{4}$ & $\begin{array}{l}\text { White or green } \\
\text { hygroscopic crystals }\end{array}$ & 1,520 & 1 & 2 & $\begin{array}{l}\text { Textile industry, manufacture of } \\
\text { paints, producing accumulators }\end{array}$ \\
\hline Iron oxide & $\mathrm{FeO}$ & $\begin{array}{l}\text { Black crystals insoluble in } \\
\text { water }\end{array}$ & 5,000 & 5 & 1 & Food industry, cosmetics \\
\hline $\begin{array}{l}\text { Sodium } \\
\text { triphosphate }\end{array}$ & $\mathrm{Na}_{5} \mathrm{P}_{3} \mathrm{O}_{10}$ & $\begin{array}{l}\text { White hygroscopic } \\
\text { crystals }\end{array}$ & 3,900 & 10 & 2 & $\begin{array}{c}\text { Food industry, production of ceramics, } \\
\text { detergents }\end{array}$ \\
\hline $\begin{array}{l}\text { Phosphoric } \\
\text { acid }\end{array}$ & $\mathrm{H}_{3} \mathrm{PO}_{4}$ & $\begin{array}{l}\text { White crystals or colorless } \\
\text { liquid soluble in water }\end{array}$ & 1,895 & 10 & 3 & $\begin{array}{l}\text { Food industry, dentistry, rust removal, } \\
\text { chemical industry }\end{array}$ \\
\hline
\end{tabular}

For key to abbreviations see Table 1. 
substrate are presented in Figures 1 and 2. Following the addition of inorganic substances, the most clearly manifested differences compared to the control were observed in the groups which consumed the substrate containing lead nitrate (body mass increased by $102.6 \%$ compared to the control, $\mathrm{P}<0.01)$ and calcium chloride (body weight increased by $89.1 \%, \mathrm{P}<0.01$ ). A significant increase was observed after addition of cobalt nitrate (by
$96.9 \%, \mathrm{P}<0.05$ ), sodium triphosphate (by $86.0 \%, \mathrm{P}<$ 0.05 ) and zinc chloride (by $83.5 \%, \mathrm{P}<0.05$ ).

An insignificant impact on the body mass of $T$. molitor was observed following addition of manganese sulfate (by $57.8 \%, \mathrm{P}>0.05$ ), aluminium nitrate (by $57.3 \%$, $\mathrm{P}>0.05$ ), iron oxide (by $51.5 \%, \mathrm{P}>0.05$ ), barium nitrate (by $47.9 \%, \mathrm{P}>0.05$ ), orthophosphoric acid (by $47.4 \%, \mathrm{P}>$ 0.05 ), manganese chloride (by $46.5 \%, \mathrm{P}>0.05$ ), cadmium

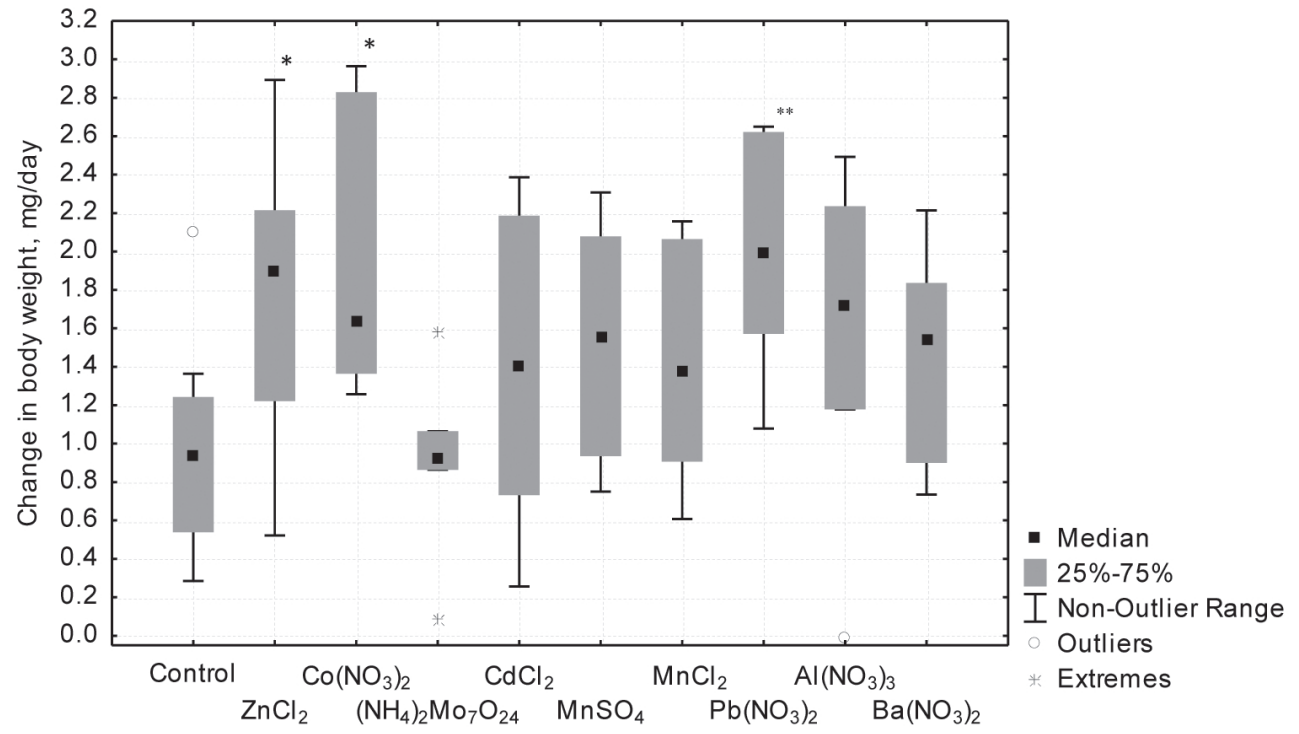

Fig. 1. Changes in the body weight of $T$. molitor over 14-day laboratory experiment with substrate including heavy metals at concentration of $350 \mathrm{mg} \mathrm{kg}^{-1}$ of fodder. ${ }^{*} \mathrm{P}<0.05, * * \mathrm{P}<0.01$.

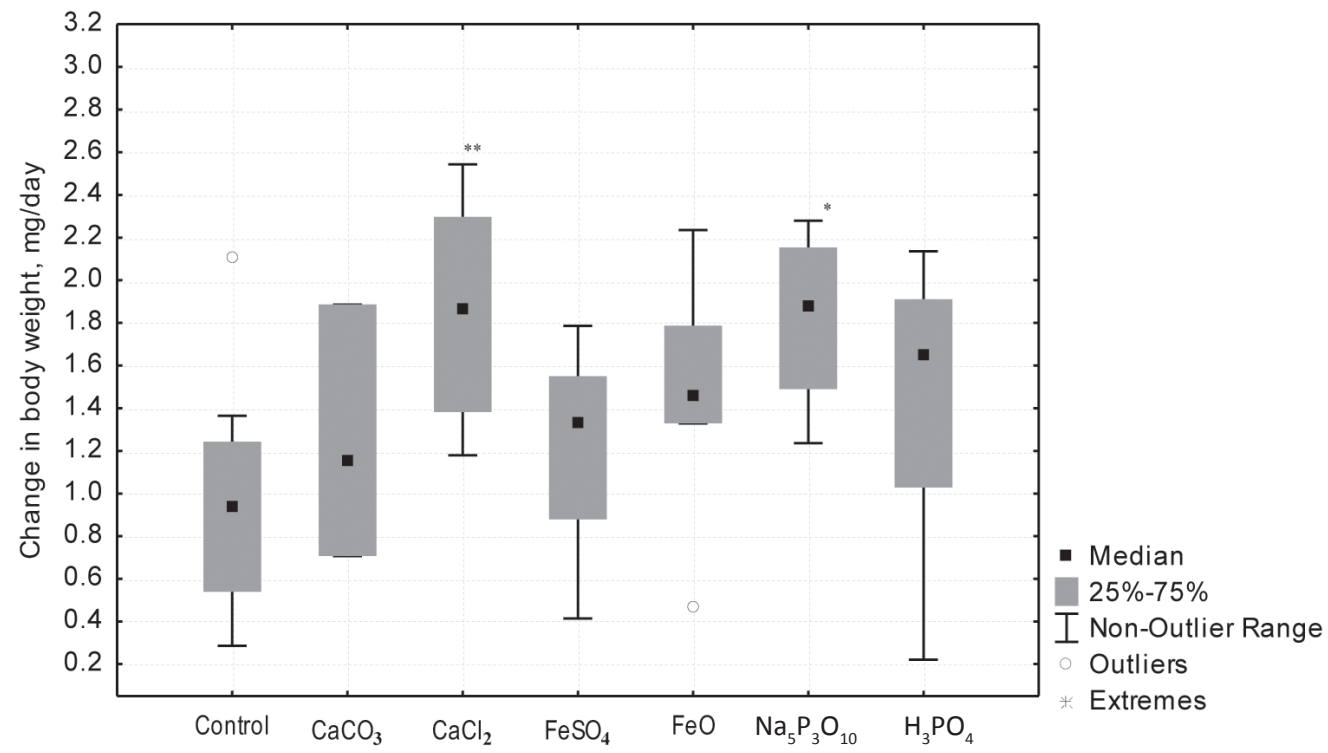

Fig. 2. Changes in the body weight of $T$. molitor over a 14-day laboratory experiment with substrate containing inorganic substances in concentration of $350 \mathrm{mg} \mathrm{kg}^{-1}$ of fodder. $* \mathrm{P}<0.05, * * \mathrm{P}<0.01$. 
chloride (by $43.9 \%, \mathrm{P}>0.05$ ), calcium carbonate (by $27.7 \%, \mathrm{P}>0.05$ ), iron sulfate (by $24.2 \%, \mathrm{P}>0.05$ ) and ammonium heptamolybdate (by $-7.5 \%, \mathrm{P}>0.05$ ).

\section{Discussion}

The results obtained indicate that the studied concentrations of inorganic substances in the diet of $T$. molitor caused an increase in the body weight of the larvae rather than a decrease. Such effect is probably related to excessive consumption of fodder and metabolic disorders in the animals' organism, which could be caused by accumulations of heavy metals in the organism (BRygadyrenko and Ivanyshin, 2014, 2015). Considering the low concentration of substances in the experiment, the observed changes, i.e. gain in weight by T. molitor, indicate a chronic toxic effect during the primary stages intoxication of the organism.

Similar results, which indicate an increase in the body weight of Eisenia foetida (Savigny, 1826) (Annelida, Lumbricidae) were presented by Van Gestel et al. (1993) for chrome and zinc. Also, disorders in reproductive activity, in cocoon formation and reduction in the number of offspring were observed. Nevertheless, many researchers have reported an opposite impact of heavy metals on body weight. Decrease in body weight was found for impact of cadmium (VAN Gestel et al., 1993; SANTANA et al., 2005), lead (WANG et al., 2015), copper (BAKER et al., 1998), aluminium (Gomez et al., 1991) and other heavy metals.

The main source of heavy metals for the organism of terrestrial arthropods is food, and the main organ of accumulation is the walls of the digestive tract (MARONI and Watson, 1985; LindQVist et al., 1995; HensBergen et al., 2000). One of the ways of detoxication of accumulated trace amounts of metals in arthropods is fixation of metallothioneins in cell cytosols (KoRSLOOT et al., 2004). LAUVERJAT et al. (1989) demonstrated apical extrusion of cadmium from the cells of the epithelium of Drosophila melanogaster (Meigen, 1830), and Posthuma et al., (1992) discovered that up to $35 \%$ of cadmium obtained by the organism of Orchesella cincta (Linnaeus, 1758) is removed every moult through removal of intestinal epithelium. Cadmium-binding proteins were discovered in some species of arthropods, such as Locusta migratoria (Linnaeus, 1758), Pteronarcys californica Newport, 1848 and others (Clubb et al., 1975; Martoja et al., 1983; Dallinger, 1993). Pedersen et al. (2007) reported the extraction of a cadmium-binding protein, different from metallothioneins, in T. molitor larvae, exposed to the impact of cadmium.

Apart from this, Pedersen et al. (2008) in a 16-day experiment with content of cadmium at $50 \mathrm{mg} 100 \mathrm{~g}^{-1}$ of fodder found that $70 \%$ of cadmium obtained by the organism of $T$. molitor was accumulated in the wall of the intestine and in its content. In other parts of the body, including the malpighian tubule system, the fat body, muscles and cuticle, the accumulation of cadmium was $11 \%$. Most of the accumulated metal was found in the digestive tract after the 16-day experiment. Transferring the larvae to non-contaminated food resulted in decrease in content of cadmium by $80 \%$, which is explained by its removal with feces.

In their study of the absorption of cadmium and zinc, Buchwalter and LuOMa (2005) found that Drunella grandis (Eaton, 1884) and D. flavilinea (McDunnough, 1926) accumulated these metals faster than the other species. The indicators of $\mathrm{Cd}$ absorption varied 250 times between Siphlonuris sp. and D. flavilinea. Similarly, the levels of $\mathrm{Zn}$ absorption varied 35 times between Ameletus sp. and D. grandis. The differences in consumption of metals were calculated through number of channels, for it was found that D. flavilinea has 266 times more transporters of cadmium than Siphlonuris sp. Coefficients of absorption of $\mathrm{Cd}$ and $\mathrm{Zn}$ from the solution vary for different species of aquatic insects by dozens of times. This variability is directly related to morphological characteristics, and finally - to osmoregulation function.

LAGISZ (2008) studied the impact on ground beetles Pterostichus oblongopunctatus (Fabricius, 1787) of cadmium at environmental concentration of $50 \mathrm{mg} \mathrm{kg} \mathrm{kg}^{-1}$ and of zinc of $500 \mathrm{mg} \mathrm{kg}^{-1}$, over 70 days. The beetles with higher initial mass had higher probability of surviving longer. Over the experiment, the average body weight decreased with both diets, though the effect was most clearly manifested among males.

A study on the impact of zinc and food containing cadmium on Poecilus cupreus (Linnaeus, 1758) was conducted by MARYANSKI et al. (2002). They found that the beetles were able to regulate efficiently the concentration of zinc. To some extent, the insects were capable of regulating the concentration of $\mathrm{Cd}$, though not so efficiently. Despite significant differences between the results for both sexes, decrease in body weight under the impact of the studied metals was observed. MircIC et al. (2010, 2013) and Vlahovic et al. $(2008,2012)$ studied the impact of cadmium on the larvae of Lymantria dispar (Linnaeus, 1758), using a concentration of Cd at $50 \mathrm{mg} \mathrm{kg}^{-1}$ of fodder. When the larvae were given food containing this dose of $\mathrm{Cd}$, the chronic effect on their body weight was found significant. The results of the study showed a significant impact of the diet containing cadmium. The duration of development of larvae was extended and the body weight reduced under the impact of $\mathrm{Cd}$. This coincided with data from the literature on other species (SCHMIDT et al., 1991; McChaton and Pascoe, 1991; Niu et al., 2002; Cervera et al., 2004; Mircic et al., 2010).

In the study on the impact of heavy metals on Aiolopus thalassinus (Fabricius, 1781) conducted by SchmidT et al. (1992), the fodder contained 10, 30 and 70 $\mathrm{mg} \mathrm{kg}{ }^{-1}$ of $\mathrm{HgCl}_{2}, 25,75$ and $100 \mathrm{mg} \mathrm{kg}^{-1}$ of $\mathrm{CdCl}_{2}$ and 75 , 200 and $500 \mathrm{mg} \mathrm{kg}^{-1}$ of $\mathrm{PbCl}_{2}$ of dry mass. At the highest concentrations of these substances, mature individuals died very early before laying eggs. At all concentrations of cadmium and mercury, extension of the duration of nymph stage was observed, which was not found with fodder containing lead. Heavy metals affected the weight 
of mature individuals, though this effect varied in relation to the metal. Mercury caused significant loss of weight among both females and males. A similar effect was observed for males which consumed cadmium. Females and males fed with the highest lead concentration were observed to decrease in body weight. On the other hand, at lower concentrations of lead, the body weight was similar to the control.

Toxicity of lead, especially if its concentration in the organism exceeds physiological thresholds, was observed for some species of insects. Disorders in the functions of organism of insects, which inhabited an environment contaminated with zinc, such as Pterostichus oblongopunctatus, Poecilus cupreus, were observed by Bisthoven et al. (1992), Martinez et al. (2001, 2002, 2004), MARYANSKi et al. (2002), LAGISZ (2008). Consumption of zinc-contaminated food by insects caused delays in their development, for example, among larvae of Aglais urticae (Linnaeus, 1758) (LINDQVIST, 1994), Trichoplusia ni (Hubner, 1800-1803) (LARSEN et al., 1994), P. oblongopunctatus (Zygmunt et al., 2006) and Issoria lathonia (Linnaeus, 1758) (NorET et al., 2007). High concentrations of $\mathrm{Zn}$ led to a low survival rate of Priosotoma minuta (Nursita et al., 2005). The effect of $\mathrm{Zn}$ on breeding insects was studied for $P$. minuta (NuRsita et al., 2005) and for the grasshopper Chorthippus brunneus (Thunberg, 1815) (AugustYNiAK et al., 2008).

The study of the impact of lead nitrate on the survival rate in aquatic insects Pteronarcys dorsata (Say, 1823), Hydropsyche betteni (H.H. Ross, 1938), Brachycentrus sp. and Phemerella sp. SPEHAR et al. (1978) revealed that a maximum dose of lead nitrate at $0.565 \mathrm{mg}^{-1}$ had no effect. ANDERSON et al. (1980) studied the impact of lead nitrate on Tanytarsus dissimilis (Johannsen, 1905) over 10 days, beginning from the egg stage: average $\mathrm{LC}_{50}$ equaled $0.258 \mathrm{mg}^{-1}$. No significant impact on the growth of the surviving larvae was observed until the concentration was raised. A study of the impact of iron and lead on mayflies Leptophlebia marginata Linnaeus, 1767 was conducted by GERHARDT (1994): the toxicity of both metals was higher at low levels of $\mathrm{pH}$. Over $96 \mathrm{~h}$ exposure, $\mathrm{LC}_{50}$ for Fe equaled $106.3 \mathrm{mg} \mathrm{l}^{-1}$ at $\mathrm{pH} 7.0$ and $89.5 \mathrm{mg} \mathrm{l}^{-1}$ at $\mathrm{pH}$ 4.5. The values of $\mathrm{Pb}$ equaled $>5 \mathrm{mg} \mathrm{l}^{-1}$ and $1.09 \mathrm{mg} \mathrm{l}^{-1}$, respectively.

A study of accumulations of aluminium in insects, carried out by HALL et al. (1988) showed that an increase in $\mathrm{pH}$ of water induced a decrease in concentration of aluminium in black flies and mayflies. Similar results were observed for chironomids (Young and HaRveY, 1988). GuEROLD et al. (1995) studied the accumulation of aluminium in chloride epithelium cells of Perla marginata Panzer, 1799. Frick and Herrmann (1990) studied the accumulation of aluminium (Al) in nymphs of the mayfly Heptagenia sulphurea (Muller, 1776). The nymphs were affected by two concentrations of $\mathrm{Al}\left(0.2\right.$ and $\left.2.0 \mathrm{mg} \mathrm{l}^{-1}\right)$ and two periods of impact ( 2 and 4 weeks); the longer time period also included the moult stage. The group of nymphs, which survived moulting, was observed to have an increase in the aluminium content almost twice $\left(2.34 \mathrm{mg} \mathrm{g}^{-1}\right.$ of dry mass) as high as the group with the two-week exposure (1.24 $\left.\mathrm{mg} \mathrm{g}^{-1}\right)$. This indicated that $\mathrm{Al}$ also accumulates inside nymphs, though most of the metal was deposited on the external part of the insects. Therefore, the insects accumulate aluminium in their cuticle and in the content of their intestine. TABAK and GIBBS (1991) evaluated the impact of aluminium and calcium on laying eggs and nymphs in Cloeon triangulifer (McDunnough, 1931). The eggs were incubated in acidic waters $(\mathrm{pH} 4.0$ and 5.5) with admixed calcium (10 and $100 \mathrm{mg} \mathrm{g}^{-1}$ ) and aluminium (100 and $\left.500 \mu \mathrm{g} \mathrm{g}^{-1}\right)$ : the admixture significantly reduced the percentage of successful moulting. Also, calcium increases the percentage of both successful and partly successful moulting. Havens (1993) studied the impact of aluminium $\left(200 \mu \mathrm{g} \mathrm{g}^{-1}\right)$ on aquatic invertebrates: it was found that aluminium significantly decreased the survival rate of Gyraulus, Hyalella and Chironomida, at the same time, the survival rate of Enallagma and Caenis at low $\mathrm{pH}$ (4-5) improved due to Al.

KIJAK et al. (2014) studied the toxic impact of aluminium on Drosophila melanogaster (Meigen, 1830). The flies were exposed to aluminium at concentrations from 40 to $280 \mathrm{mg} \mathrm{kg}^{-1}$ in the food substrate. The study measured the life expectancy of insects exposed to the impact of aluminium $\left(40,120\right.$ or $240 \mathrm{mg} \mathrm{kg}^{-1}$ of $\mathrm{Al}$ in the fodder) at different stages of their life cycle. The results showed that aluminium is toxic in concentrations higher than $160 \mathrm{mg} \mathrm{kg}^{-1}$ in the feed. The life expectancy of the flies was reduced in relation to concentration of $\mathrm{Al}$ and the duration of exposure. Average concentrations (120 mg kg$\left.{ }^{1}\right)$ of $\mathrm{Al}$ had a stimulating effect on the males, improving their life expectancy and locomotion activity.

The reactions of broad-nosed weevil Phyllobius arborator (Herbst, 1797) to enhanced concentration of manganese in the diet were studied by MARTINEK et al. (2017). The broad-nosed weevils were fed with birch (Betula pendula Roth) leaves soaked in solutions of $\mathrm{MnCl}_{2}$ with graduated concentrations of manganese. Even significantly high consumption of manganese did not cause changes in reactions of the $P$. arborator imagoes compared to the control. The study did not find significant differences in food consumption, body weight of the imagoes and duration of their feeding period. It was found that $P$. arborator avoided manganese intoxication through food by releasing manganese into the feces or by neutralizing manganese in relatively high concentrations. Kula et al. (2014) studied the reaction of Lymantria dispar (Linnaeus, 1758) to the content of manganese in food during laboratory breeding of the caterpillars. The caterpillars were fed with leaves of birch soaked in solutions of $\mathrm{MnCl}_{2}$ at concentrations of $0,0.5,5$ and $10 \mathrm{mg} \mathrm{kg}^{-1}$, the content of manganese equaled 307, 632, 4,087 and 8,124 $\mathrm{mg} \mathrm{kg}^{-1}$. High concentration of manganese in the food affected the process of development. The death rate of the caterpillars of the first stage was $8 \%$ and $62 \%$ at the highest content of manganese. The study observed an increase in the periods of development and in consumption of food. The main 
strategy of caterpillars' defense is accumulating metal in their cover. With imagoes the content of manganese decreased to $0.5 \%$ of the consumption even under maximum concentrations.

Sorensen et al. (2009) studied the survival rate of a cosmopolitan insect Megaselia scalaris (Loew, 1866), exposed to a Mn concentration of 2,600 mg kg-1 of dry mass. The insects with a diet Mn 260-2,600 mg kg-1 showed a significant decrease in the duration of their larval development, total duration of imago formation and breeding. Also an increase in the width of the females' wings was observed. The timing of hatching, the number of females and the wing length of the males did not differ from the control.

GONGALSKY (2006) studied the accumulation of molybdenum in soil insects around the areas of uranium mining. The author found that the concentration of molybdenum in the insects equaled $1.4-8.5 \mathrm{mg} \mathrm{kg}^{-1}$, which is 2-12 times higher compared to the insects in the control area. High concentrations were found in Poecilus gebleri (Dejean, 1828), P. fortipes (Chaudoir, 1850), Nicrophorus investigator (Zetterstedt, 1824), Blaps rugosa (Gebler, 1825), Angaracris barabensis (Pallas, 1773). The insects most susceptible to accumulating metal were found to be saprophagous darkling beetles.

The toxicity of barium carbonate for Sarcophaga ruficornis (Fabricius, 1794) was studied by SiNGH et al. (2017). They found a significant death rate in the pupae, despite the absence of changes at the larval stage. A maximum concentration of $10,000 \mathrm{ppm}$ caused death of $26.6 \%$ of the pupae and $73.3 \%$ of the imagoes. The observed mortality of the pupae was directly related to the concentration.

Despite the significant amount of studies on the impact of heavy metals on insects, it should be mentioned that there is insufficient information on particular compounds of salts and metals, and also on the impact of these substances on particular species. According to our research, T. molitor is a good model for studying the impact of heavy metals and other, substances delivered to insects with food.

\section{Conclusions}

A significant gain in the body weight in T. molitor larvae was caused by adding $350 \mathrm{mg} 1 \mathrm{~kg}^{-1}$ of lead nitrate, cobalt nitrate, calcium chloride, sodium triphosphate and zinc chloride to the larvae's fodder. We observed a tendency towards increase in the body weight in larvae of T. molitor after adding manganese sulfate, aluminium nitrate, iron oxide, barium nitrate, orthophosphoric acid, manganese chloride, cadmium chloride, calcium carbonate and iron sulfate in the same concentrations.

Therefore, 5 out of the 15 studied inorganic substances reliably stimulated the gain in body weight of the third stage T. molitor larvae, and 7 manifested properties at the level of tendency (stimulated an increase in mass on average by $43-58 \%$ over the 14 -day experiment). These data contradict a significant amount of data from the literature which states that pollutants reduce the body weight in the model insect species. The study of the impact of heavy metals on insect organisms is significant for protecting rare species in the conditions of industrial and agricultural pollution. The conservation of these species requires development of methods for evaluating the hazard of negative impacts on the organisms of invertebrates and development of measures for eliminating such negative impacts.

\section{References}

Anderson, R.L., Walbridge, C.T., Fiandt, J.T., 1980. Survival and growth of Tanytarsus dissimilis (Chironomidae) exposed to copper, cadmium, zinc and lead. Archives of Environmental Contamination and Toxicology, 9: 329-335.

Augustyniak, M., Babczynska, A., Kozlowski, M., Sawczyn, T., Augustyniak, M., 2008. Effects of zinc and female aging on nymphal life history in a grasshopper from polluted sites. Journal of Insect Physiology, 54: 4150.

Baker, R.T.M., Handy, R.D., Davies, S.J., Snook, J.C., 1998. Chronic dietary exposure to copper affects growth, tissue lipid peroxidation, and metal composition of the grey mullet, Chelon labrosus. Marine Environmental Research, 45: 357-365.

Bisthoven, L.G., Timmermans, K.R., Ollevier, F., 1992. The concentration of cadmium, lead, copper and zinc in Chironomus thummi larvae Diptera, Chironomidae with deformed versus normal menta. Hydrobiology, 239: 141149.

Braeckman, B., Smagghe, G., Brutsaert, N., Cornelis, R., RaEs, H., 1999. Cadmium uptake and defense mechanism in insect cells. Environmental Research, 80: 231-243.

Brygadyrenko, V.V., Ivanyshin, V.M., 2014. Impact of ferric salt on body weight of Megaphyllum kievense (Diplopoda, Julidae) and litter granulometric composition in the laboratory experiment. Visnyk of Dnipropetrovsk University. Biology, Ecology, 22: 83-87.

Brygadyrenko, V.V., Ivanyshyn, V.M., 2015. Changes in the body mass of Megaphyllum kievense (Diplopoda, Julidae) and the granulometric composition of leaf litter subject to different concentrations of copper. Journal of Forest Science, 61: 369-376.

Brygadyrenko, V.V., Reshetniak, D.Y., 2014. Morphological variability among populations of Harpalus rufipes (Coleoptera, Carabidae): What is more important - the mean values or statistical peculiarities of distribution in the population? Folia Oecologica, 41, 109-133.

Buchwalter, D.B., Luoma, S.N., 2005. Differences in dissolved cadmium and zinc uptake among stream insects: Mechanistic explanations. Environmental Science and Technology, 39: 498-504.

Cervera, A., Mayamo, A.C., Sendra, M., MartinezPardo, R., Garcera, M.D., 2004. Cadmium effects on development and reproduction of Oncopeltus fasciatus (Heteroptera: Lygaeidae). Journal of Insect Physiology, 50: 737-749. 
Clubb, R.W., LoRds, J.L., Gaufin, A.R., 1975. Isolation and characterization of a glycoprotein from stonefly, Pteronarcys californica, which binds cadmium. Journal of Insect Physiology, 21: 53-60.

Dallinger, R., 1993. Strategies of metal detoxification in terrestrial invertebrates. In DALLINGER, R., RAINBOW, P.S. (eds.) Ecotoxicology of metals in invertebrates. Boca Raton: Lewis Publishers, p. 245-289.

Frick, K.G., Herrmann, J., 1990. Aluminum accumulation in a lotic mayfly at low $\mathrm{pH}$ - a laboratory study. Ecotoxicology and Environmental Safety, 19: 81-88.

Gerhardt, A., 1994. Short term toxicity of iron (Fe) and lead $(\mathrm{Pb})$ to the mayfly Leptophlebia marginata (L.) (Insecta) in relation to freshwater acidification. Hydrobiologia, 284 (2): $157-168$.

Gomez, M., DomingO, J.L., LoBet, J.M., 1991. Developmental toxicity evaluation of oral aluminum in rats: Influence of citrate. Neurotoxicology and Teratology, 13: 323-328.

GoNGALSKY, K.B., 2006. Bioaccumulation of metals by soildwelling insects in a uranium production area. European Journal of Soil Biology, 42: 180-185.

Guerold, F., Giamberini, L., Tourmann, J.-L., Pihan, J.-C., Kaufmann, R., 1995. Occurrence of aluminum in chloride cells of Perla marginata (Plecoptera) after exposure to low $\mathrm{pH}$ and elevated aluminum concentration. Bulletin of Environmental Contamination and Toxicology, 4: 620-625.

Hall, R.J., Bailey, R.C., Findeis, J., 1988. Factors affecting survival and cation concentrations in the blackflies Prosimulium fuscum/mixtum and the mayfly Leptophlebia cupida during spring snowmelt. Canadian Journal of Fisheries and Aquatic Sciences, 45: 2123-2132.

Havens, K.E., 1993. Acid and aluminum effects on the survival of littoral macro-invertebrates during acute bioassays. Environmental Pollution, 80: 95-100.

Hensbergen, P.J., Van Velzen, M.J.M., Nugroho, R.A., Donker, M.H., Van Straalen, N.M., 2000. Metallothionein-bound cadmium in the gut of the insect Orchesella cincta (Collembola) in relation to dietary cadmium exposure. Comparative Biochemistry and Physiology-Part C: Toxicology and Pharmacology, 125: $17-24$.

Kijak, E., Rosato, E., Knapczyk, K., Pyza, E., 2014. Drosophila melanogaster as a model system of aluminum toxicity and aging. Insect Science, 21: 189-202.

Korsloot, A., Van Gestel, C.A.M., Van Straalen, N.M., 2004. Environmental stress and cellular response in arthropods. In AHMAD, S. (ed). Herbivorous insects: hostseeking behavior and mechanisms. New York: Academic Press, p. 210-224.

Kula, E., MartineK, P., Chromcova, L., Hedbavn, J., 2014. Development of Lymantria dispar affected by manganese in food. Environmental Science and Pollution Research, 21: 11987-11997.

LAGISZ, M., 2008. Changes in morphology of the ground beetle Pterostichus oblongopunctatus F. (Coleoptera; Carabidae) from vicinities of a zinc-and-lead smelter. Environmental Toxicology and Chemistry, 27: 1744-1747.

Larsen, K.J., Litsch, A.L., Brewer, S.R., Taylor, D.H., 1994. Contrasting effects of sewage sludge and commercial fertilizer on egg to adult development of two herbivorous insect species. Ecotoxicology, 3: 94-109.

Lauverjat, S., Ballan-Dufrancias, C., Wegnez, M., 1989. Detoxification of cadmium. Ultrastructural study and electron-microprobe analysis of the midgut in a cadmiumresistant strain of Drosophila melanogaster. Biology of Metals (Berlin), 2: 97-107.

LINDQVIST, L., 1994. Metal uptake and accumulation during growth of Aglais urticae (Lepidoptera: Nymphalidae) larvae. Environmental Entomology, 23: 975-978.

LindQvist, L., Block, M., TJalve, H., 1995. Distribution and excretion of $\mathrm{Cd}, \mathrm{Hg}$, methyl- $\mathrm{Hg}$ and $\mathrm{Zn}$ in the predatory beetle Pterostichus niger (Coleoptera, Carabidae). Environmental Toxicology and Chemistry, 14: 11951201.

Maroni, G., Watson, D., 1985. Uptake and binding of cadmium, copper and zinc by Drosophila melanogaster larvae. Insect Biochemistry, 15: 55-63.

MartineK, P., Kula, E., HedbávnÝ, J., 2017. Reaction of leaf weevil Phyllobius arborator (Coleoptera: Curculionidae) to manganese content in diet. Environmental Entomology, 46: 131-136.

Martinez, E.A., Moore, B.C., Schaumloffel, J., Dasgupta, N., 2001. Induction of morphological deformities in Chironomus tentans exposed to zinc- and lead-spiked sediments. Environmental Toxicology and Chemistry, 20: 2475-2481.

Martinez, E.A., Moore, B.C., Schaumloffel, J., DasGupta, N., 2002. The potential association between menta deformities and trace elements in Chironomidae (Diptera) taken from a heavy metal contaminated river. Archives of Environmental Contamination and Toxicology, 42: 286-291.

Martinez, E.A., Moore, B.C., Schaumloffel, J., DasGupta, N., 2004. Effects of exposure to a combination of zincand lead-spiked sediments on mouthpart development and growth in Chironomus tentans. Environmental Toxicology and Chemistry, 23: 662-667.

Martoja, R., Bouquegneau, J.M., Verthe, C., 1983. Toxicological effects and storage of cadmium and mercury in an insect Locusta migratoria (Orthoptera). Journal of Invertebrate Pathology, 42: 17-32.

Martynov, V.O., Brygadyrenko, V.V., 2017. The influence of synthetic food additives and surfactants on the body weight of larvae of Tenebrio molitor (Coleoptera, Tenebrionidae). Biosystems Diversity, 25: 236-242.

Maryanski, M., Kramarz, P., Laskowski, R., Niklinska, M., 2002. Decreased energetic reserves, morphological changes and accumulation of metals in carabid beetles (Poecilus cupreus L.) exposed to zinc- or cadmiumcontaminated food. Ecotoxicology, 11: 127-139.

McChaton, C.P., Pascoe, D., 1991. Brief exposure of first and fourth instar Chironomus riparius larvae to equivalent assumed doses of cadmium: Effects on adult emergence. Water, Air, and Soil Pollution, 60: 395-403.

Mircic, D., Blagojevic, D., Peric-Mataruga, V., Ilijin, L., Mrdakovic, M., Vlahovic, M., Lazarevic, J., 2013. Cadmium effects on the fitness-related traits and antioxidative defense of Lymantria dispar L. larvae. Environmental Science and Pollution Research, 20: 209218.

Mircic, D., Jankovic-Tomanic, M.Z., Nenadovic, V.A., Franeta, F., Lazarevic, J.M., 2010. The effects of 
cadmium on the life history traits of Lymantria dispar L. Archives of Biological Sciences, 62: 1013-1020.

Niu, C.-Y., Jiang, Y., Lei, C.-L., Hu, C., 2002. Effects of cadmium on housefly: influence on growth and development and metabolism during metamorphosis of housefly. Insect Science, 9: 27-33.

Noret, N., Josens, G., Escarre, J., Lefebvre, C., Panichelli, S., MeErTs, P., 2007. Development of Issoria lathonia (Lepidoptera: Nymphalidae) on zinc-accumulating and nonaccumulating Viola species (Violaceae). Environmental Toxicology and Chemistry, 26: 565-571.

Nursita, A.I., Balwant, S., Lees, E., 2005. The effect of cadmium, copper, lead, and zinc on the growth and reproduction of Priosotoma minuta Tullberg (Collembola). Ecotoxicology and Environmental Safety, 60: 306-314.

Pedersen, S.A., Kristiansen, E., Andersen, R.A., ZACHARIASSEN, K.E., 2007. Isolation and preliminary characterization of a Cd-binding protein from Tenebrio molitor (Coleoptera). Comparative Biochemistry and Physiology - Part C: Toxicology and Pharmacology, 145: 457-463.

Pedersen, S.A., Kristiansen, E., Andersen, R.A., ZaChariassen, K.E., 2008. Cadmium is deposited in the gut content of larvae of the beetle Tenebrio molitor and involves a Cd-binding protein of the low cysteine type. Comparative Biochemistry and Physiology - Part C: Toxicology and Pharmacology, 148: 217-222.

Posthuma, L., Hogervorst, R., Van Straalen, N.M., 1992. Adaptation to soil pollution by cadmium excretion in natural populations of Orchesella cincta (L.) (Collembola). Archives of Environmental Contamination and Toxicology, 22: 146-156.

Santana, M.G., Moraes, R., Bernardi, M.M., 2005. Toxicity of cadmium in Japanese quail: evaluation of body weight, hepatic and renal function, and cellular immune respons. Environmental Research, 99: 273-277.

Schmidt, G.H., Ibrahim, N.M.M., AbDallah, M.D., 1991. Toxicological studies on the long-term effects of heavy metals $(\mathrm{Hg}, \mathrm{Cd}, \mathrm{Pb})$ in soil on the development stages of Aiolopus thalassinus (Saltatoria: Acrididae). Science of the Total Environment, 107: 109-133.

Schmidt, G.H., Ibrahim, N.M.M., AbDallah, M.D., 1992. Long-term effects of heavy metals in food on developmental stages of Aiolopus thalassinus (Saltatoria: Acrididae). Archives of Environmental Contamination and Toxicology, 23: 375-382.

Shulman, M.V., Pakhomov, O.Y., Brygadyrenko, V.V., 2017. Effect of lead and cadmium ions upon the pupariation and morphological changes in Calliphora vicina (Diptera, Calliphoridae). Folia Oecologica, 44: 26-35.

Singh, Z., Singh, A., Kaur, M., Kaur, T., 2017. Assessment of barium carbonate toxicity on the developmental stages of Sarcophaga ruficornis (Diptera: Sarcophagidae). International Journal of Current Microbiology and Applied Sciences, 6: 485-494.

Sorensen, M.A., Chase-Dunn, C.M., Trumble, J.T., 2009. Chronic exposure to elevated levels of manganese and nickel is not harmful to a cosmopolitan detritivore, Megaselia scalaris (Diptera: Phoridae). Insect Science, 165: 73-79.

Spehar, R.L., Anderson, R.L., FiAndt, J.T., 1978. Toxicity and bioaccumulation of cadmium and lead in aquatic invertebrates. Environmental Pollution, 15: 195-208.

TABAK, L.M., GIBBS, K.E., 1991. Effects of aluminum, calcium and low $\mathrm{pH}$ on egg hatching and nymphal survival of Cloeon triangulifer McDunnough (Ephemeroptera: Baetidae). Hydrobiologia, 218: 157-166.

VAlko, M., Morris, H., Cronin, M.T., 2005. Metals, toxicity and oxidative stress. Current Medical Chemistry, 12: 1161-1208.

Van Gestel, C.A.M., Dirven-van Breemen, E.M., BAERSELMAN, R., 1993. Accumulation and elimination of cadmium, chromium and zinc and effects on growth and reproduction in Eisenia andrei (Oligochaeta, Annelida). Science of the Total Environment, 134: 585-597.

Vlahovic, M., Lazarevic, J., Peric-Mataruga, V., Ilijin, L., Mrdakovic, M., 2008. Plastic responses of larval mass and alkaline phosphatase to cadmium in the gypsy moth larvae. Ecotoxicology and Environmental Safety, 72: 1148-1155.

Vlahovic, M., Peric-Mataruga, V., Ilijin, L., Mrdakovic, M., Mircic, D., Todorovic, D., Lazarevic, J., 2012. Changes in activity of nonspecific esterases in cadmium treated Lymantria dispar larvae. Ecotoxicology, 21: 370378.

Wang, J., Ren, T., Han, Y., ZhaO, Y., LiaO, M., Wang, F., JIANG, Z., 2015. The effects of dietary lead on growth, bioaccumulation andantioxidant capacity in sea cucumber, Apostichopus japonicus. Environmental Toxicology and Pharmacology, 40: 535-540.

Young, L.B., Harvey, H.H., 1988. Metals in chironomidae larvae and adults in relation to lake $\mathrm{pH}$ and lake oxygen deficiency. Verhandlungen des Internationalen Verein Limnologie, 23: 246-251.

Zygmunt, P.M., Maryanski, M., Laskowski, R., 2006. Body mass and caloric value of the ground beetle (Pterostichus oblongopunctatus) (Coleoptera, Carabidae) along a gradient of heavy metal pollution. Environmental Toxicology and Chemistry, 25: 2709-2714.

Received December 12, 2017 Accepted April 4, 2018 